\author{
Irena Novak Popov \\ Filozofska fakulteta, Ljubljana \\ DOI: $10.4312 /$ SSJLK.57.53-62
}

\title{
Nove poetike sodobnih slovenskih pesnic
}

Prispevek predstavlja poezijo treh pesnic, Anje Golob, Nine Dragičević in Kaje Teržan, ki so v zadnjem času obogatile slovensko pesniško krajino in prejele prestižne nagrade. Konstrukt ženskega spola je $v$ njihovih zbirkah razviden iz situacij, položajev, izkušenj, intimnih odnosov ter iz pojmovanja subjekta, pomanjšanega, nesrediščnega, razpršenega, nastajajočega v komunikaciji in čustvenih odnosih. Čeprav je ženska travmatizirana, ustrahovana in v podrejenem položaju, kljubuje družbenim normam, vztraja pri osebni svobodi in samostojnosti, bori se za preživetje na družbenem robu in brani pred vdorom nasilja v zasebni prostor in duševnost. Pesnice živijo od umetnosti in za umetnost, zato so jezikovno in oblikovno inovativne. Zgodbeno linearnost zamenjujejo z združevanjem fragmentov, v opise vnašajo čutne, čustvene vidike in ritem, monološki govor dinamizirajo z več perspektivami in glasovi. Namesto vertikalnih razmerij moči poudarjajo horizontalne vezi med enakovrednimi, namesto konformizma (maske, videza, vloge, funkcije) stavijo na občutljivo in gibljivo telo.

sodobna poezija žensk, družbeni spol, subjekt, intimni in družbeni odnosi, eksistencialni pomen ustvarjanja, jezikovne inovacije

The paper presents the work of three female poets - Anja Golob, Nina Dragičević and Kaja Teržan - who in recent times have enriched the Slovene poetic scene and received prestigious awards. In their collections, the social construct of the female gender is visible in situations, roles, experiences and personal relations, as well as in the conception of the subject - diminished, marginal, diffuse, nascent - in communication and emotional relations. Although the woman is traumatised, intimidated and in a subservient position, she challenges social norms, insists on personal freedom and independence, fights for survival at the social margins, and defends herself against violent incursions into her personal space and psyche. Female poets live from art and for art, and so they are linguistically and formally innovative. They replace the linear story with combined fragments; to descriptions they bring sensual, emotional aspects and rhythm; they bring dynamism to monologue by using multiple perspectives and voices. Instead of vertical power relations, they emphasise horizontal connections between equals; instead of conformism (masks, appearances, roles, functions), they bet on the sensitive and flexible body.

contemporary female poetry, social gender, subject, personal and social relations, existential meaning of creativity, linguistic innovation

Slovenska pesniška krajina se je $v$ zadnjih dveh desetletjih močno spremenila glede na številčnost odličnih avtoric. Tega ne kaže le število objavljenih zbirk, temveč po desetletjih spregledov tudi nagrade za poezijo, Jenkova (od 1986), Veronikina (od 1997) in nagrada Prešernovega sklada (od 1962). Trem lavreatkam v novem stoletju, Eriki Vouk, Maji Vidmar, Taji Kramberger, se je naslednje desetletje pridružila deseterica: Barbara Korun, Kristina Hočevar, Petra Kolmančič, Meta Kušar, Cvetka Lipuš, Anja Golob, Ana Makuc, Veronika Dintinjana, Alenka Jovanovski, Kaja Teržan. Med nominiranimi deli, ki jih izbirajo člani Društva slovenski literarnih kritikov za nagrado kritiško sito (od 2012), so še zbirke Katje Perat, Nine Dragičević in Vesne Liponik. ${ }^{1}$ Od izbora za tretjo knjigo Antologije slovenskih pesnic (2007) je kvalitetno pisanje žensk močno naraslo, tako

1 Merilo zanimivih novosti postavljajo tudi mladi kritiki festivala Pranger, ki izbirajo vsak po tri najboljše zbirke preteklega leta. Od leta 2004 so poleg omenjenih izbrali še zbirke 25 drugih pesnic. 
da že presega možnost kompetentnega strokovnega spremljanja. ${ }^{2}$ Množičnost je presenetljiva, saj v neoliberalni ekonomiji literarno založništvo ne prinaša profita, velike založbe se poeziji odrekajo in jo predajajo alternativnim, naklade se zmanjšujejo, dnevni tisk ne daje več prostora sprotni kritiki. ${ }^{3}$ Pesnice se celo odločajo za poklicno literarno kariero in ob skromnih honorarjih ustvarjalni čas posvečajo tudi mnogim obliterarnim dejavnostim, od organiziranja dogodkov in delavnic, kritiškega pisanja, urednikovanja do nastopanja na pesniških festivalih in gostovanj v tujini. Vse imajo univerzitetno izobrazbo, so literarno razgledane, tudi po tujih ženskih tradicijah, zato je njihova poezija stkana iz mnogih kulturnih in simbolnih kodov, nasičena s filozofsko, sociološko, antropološko, zgodovinsko in umetnostno erudicijo. Z vsebinsko brezbrežnostjo in oblikovno nepredvidljivostjo predpostavljajo občutljivega bralca, ki se je pripravljen soočiti s specifično izkušnjo in refleksijo zapletene, negotove sodobne resničnosti.

V poeziji Anje Golob (1976), Nine Dragičević (1984) in Kaje Teržan (1986) bom opazovala prežemanje intimnih in družbenih prostorov, urbanosti in narave, telesne navzočnosti in refleksivnega odzivanja. Zanimali me bodo značilni motivi in teme, predstavljanje subjektnosti ter večglasje oziroma več perspektiv. Pesnice bom prikazala z osnovnimi bio- in bibliografskimi podatki ter sintetično skicirala njihove umetniške dosežke.

Pesnica, urednica, kritičarka in založnica Anja Golob je odraščala na Koroškem (Prevalje), $v$ Ljubljani študirala filozofijo in primerjalno književnost, pisala gledališke kritike, članke in kolumne, delala kot dramaturginja in prevajalka. Leta 2013 je s prijatelji ustanovila založbo VigeVageKnjige, ki izdaja stripe in risoromane. Objavila je štiri opazne zbirke: V roki (2010), Vesa v zgibi (2013), Didaskalije k dihanju (2016), ki jo je iz protesta nad ravnanjem založb z avtorji založila sama. Četrto zbirko, naslovljeno kar s celo uvodno pesmijo da ne da ne bo več prišla da ne bo da me žge da se odganjam /.../ (2019), je v celoti prebrala publiki v štirih slovenskih krajih. Druga in tretja zbirka sta prejeli prestižno Jenkovo nagrado, ${ }^{4}$ zadnja nagrado kritiško sito. Ker so njene zbirke razprodane, je prve tri ponatisnila v eni knjigi (2018). Nemški prevod izbranih pesmi iz druge zbirke ab und zu neigungen in celotna tretja zbirka Anweisungen zum Atmen sta izšli na Dunaju. Bivanja v tujini ji omogočajo pisateljske štipendije. V intervjujih zagovarja nepopustljivost in skrajno resno pojmovanje umetnikove vloge $v$ družbi. Pretekla javna dejanja, kritiške odzive in napoved dogodkov objavlja na svoji spletni strani (www.anjagolob.org).

Zbirka $V$ roki z naslovi razdelkov tematsko nakazuje subjektovo identiteto (Znotraj), odnose (Med) in vstop v javnost (Zunaj). Ironično-fantastični uvod Kaj naj z vso to Svobodo? govori o predpogoju eksistence, čeprav se bo ta ideal materializiral šele takrat, ko/če bo svoboda sestopila z neba, se križala z gnusnimi bitji v globini in postala podlaga za človekovo hojo. Sebe pesnica predstavlja z avtobiografskimi drobci - poškodovano in s pečati zdravljeno oko - ali simbolično z organsko metaforo drobnega semena, ki vsebuje vse možnosti razvitja skozi celične delitve.

2 Tudi za pesnice velja ugotovitev, da je "slika sodobne pesniške produkcije na Slovenskem razpršena, parcialna, nesistematizirana in kot celota nereflektirana (Novak Popov 2019: 279).

3 O globinski transformaciji literarnega sistema v obdobju tranzicije glej Četrt stoletja spremenljivih zvezd (Kolšek 2017).

4 Kljub prekarnemu položaju svobodne umetnice je leta 2014 denarni del nagrade zavrnila, ker je izviral iz privatnih sredstev. 
Proces individuacije je zapuščanje zapredka, Platonove votline senc, kjer vladajo "samo-prevare, dvom in melanholija / neznane vijuge nerazumnega, / neslišnega brezčasja, « in naporno vstopanje v realnost, učenje drugačnih običajev, govoric in zgodb (Pot do rojstva).

Pripovedne pesmi so duhovito spraševanje, ali je posameznikovo življenje izid naključij, izbir ali vnaprej določno. Tako naj bi pesničina ljubezen do gledališča izhajala iz poimenovanja po dramski osebi iz Češnjevega vrta A. P. Čehova, samo rojstvo pa iz srečnega naključja, da je njena mama kot otrok čudežno preživela eksplozijo v domačem kraju. Nasprotno pa naj bi vrtnar, ki je v spomin na sinovo rojstvo kupil vse časopise tistega dne, s tem določil, da bo odrasli sin umrl kot vojni poročevalec. Groteskni konec pripovedi mladega izseljenca zamaje pojem svobodne izbire, saj se po neuresničenih "ameriških sanjah" sam ustreli s podarjeno ameriško pištolo. $Z$ ironičnimi hiperbolami pesnica razgradi dominanten položaj moškega/brata, s skromnostjo in blago samoironijo pa razdre mit o genialnem pesniku ter mukotrpnem ustvarjanju; njej se namreč poezija kar sama dogaja, presenetijo jo "zaporedja besed, / ki se ena drugi lepo prilegajo. / Potem si mislim, da je to pesem." (Nič takega - pesem)

Med duhovitimi, intelektualno izbrušenimi in čustveno zavzetimi analizami intimnih odnosov $\checkmark$ razdelku Med izstopa refleksija o fragmentu iz dela prve evropske pesnice Vse je treba tvegati, kajti (Sapfo). Do tveganja, vztrajanja ali prilagoditve/vdaje se pesnica opredeli vitalistično: "Dokler obstaja kakršnakoli možnost dviga, / tvegati padec, razbitje, izničenje / namreč ni stvar izbire, marveč nezavedne nujnosti. / Kot dihanje. «A bistveno je opozorilo, tveganje vsega je izzivanje smrti (samomora). Intima se z ljubljene osebe razširja na priljubljeni Berlin, otroške počitniške spomine, minula erotična razmerja, poletna potovanja mladih z vlakom, knjigarne s prevedeno slovensko poezijo. K zapletenosti čustev prispeva stigmatizacija lezbične ljubezni, kajti strah mrtviči živo strast, potiska v temo, pesimizem, nesproščenost. Trenutek užitka, ko "se moje telo po sredini razpara, / raztrga in razpre, / da se sredica utekočini in izvotli v srebrno sfero, / ki lebdi nad nama še dolgo po tem«, je fikcija, Podoba iz sanj, prave sanje ponoči pa so paranoični scenariji. Zbirko zaključuje pesem Izdajalka s spoznanjem o nujnosti objave: to sicer avtorico pesmi odtuji, toda brez bralca bi vsa notranja vsebina v njej odmrla, zato izdaja tu ni škodljiv prelom zaupanja, ampak bistvo komunikacije: »izdati se moram / če naj se ne izdam."

Jezikovna igrivost in resna refleksija se razmahneta v zbirki Vesa $v$ zgibi. Pesem Ravnotežje to prisilno držo, test telesne vzdržljivosti, uporabi kot metaforo za protislovja v življenju, brez ravnotežja, enakosti in pripadanja: »Ta absolutna neznosnost nenehnega / izenačevanja, ta absurdna potreba dvojega, / vsaj po nečem soditi v isto, pripadati.« To ni afirmacija individualizma, ampak zamejitev na osebno izkušnjo, ki je relativna, kontingenčna, začasna, vendar subjektova "dolžnost / zaveza / svetu / sebi« ter "pravica / biti. «(Še) Pesnica preigrava besedilne strategije, ki relativizirajo subjektivnost in racionalnost. Opise in pripovedi vodi do nepričakovane, paradoksne poante: npr. sreča je odsotnost možnih nezgod; tudi najmanjše uničeno bitje pušča praznino; telo je avtonomno, pomensko prazno mesto; čas je kategorija človekovega interesa; tekmovanje med ženskami je posledica ponotranjenih patriarhalnih pojmov. Tudi natančen opis učinkuje pretresljivo, ko prikazuje samorazdejanje živali in zamenjavo organskih delov z umetno snovjo. Izjave $v$ množini so pripisane neimenovani skupini, npr. pisateljem, ki se dopolnijo šele v branju, hrepenečim zaljubljencem, razočaranim in smisel iščočim mladim ljudem, opazovalcem skritih con 
bleščeče evropske metropole. Subjektova podoba se oblikuje v nagovoru sebe kot druge osebe. Ekspresivno moč izpovedi o globoko zakopanih stiskah, strahovih in poželenju nosi živalska in telesna simbolika, bolj samoironičen pa je načrt za učenje francoščine. Dvojinski govor posreduje ljubezenske izjave, ki ne skrivajo problematičnosti odnosa: utrujenosti, napetosti pred razhodom, nerazdružljive samosti dveh, priznanja lastnih pomanjkljivosti. Erotika je predvsem želja, ki jo intenzivira neuresničljivost. Kopičenje in stopnjevanje zamišljenih dejanj ustvarja pričakovanje, toda vrhunec užitka umanjka. Vendar so čustva kljub pogrešanju, odsotnosti, razdalji dokaz živosti, dostop do iracionalnih razsežnosti subjektivitete. Svobodna razpoložljivost in pristna nagnjenost $\mathrm{k}$ drugemu osmišljata bivanje in odmikata samost in negibnost.

Didaskalije $k$ dihanju uvaja angleški citat pesnika Marka Stranda, da v življenju ni bistvena popolnost, kar potrjuje pesničino težnjo po človeški meri, omejevanju lastnih potreb in predanosti, zvestobi, celo tveganju: "Da bi šlo enkrat, četudi le enkrat, enkrat samkrat, / zares. Ni nor, samo živel bi rad, in za življenje vse tvegal, brez kajti." (Mreža nad manežo) Temeljni vzgib besedilnega subjekta je izreči zavezujoče vrednotenje skozi čutno, čustveno in miselno navzočnost. Njena izkušnja ni najboljša možnost, vendar je alternativa zapovedani popolnosti, obilju in uspehu. Temu je mogoče slediti na oblikovni in vsebinski ravni ter $v$ zasnovi pesniškega subjekta, izjavljanja v okviru jaz - tu - zdaj in izpostavljanja ambivalentnih lastnosti srca. Oblikovna novost so eksperimenti z vizualnostjo (umik verzov $v$ desno, različne dolžine, oblika kroga, same velike ali same male črke, tujejezične pisave v izvirnih imenih oseb in krajev) in s kompozicijo, ki jo vodi združevanje mnogih detajlov, ciklično povezovanje, variacija motiva, vnašanje dejstev in citatov.

Na tematski ravni se prepletejo bivanjska, pesniška, družbenokritična in erotična tema. Bivanjska zajema premislek o smislu, sreči in osebnem idealizmu, ki jih pesmi Ambalama, Morska pesem, Jesení uprizarjajo kot brezčasno harmonijo v lepem naravnem okolju. Za Anjo Golob je pisanje poezije resno profesionalno delo in ne prostočasni hobi amaterjev: "aranžerji animatorji / maškare in antropomorfne pokveke / gremo gremo / v soncu stojite / in ne mečete nobene sence« (Hobi), jezikovna komunikacija in empatija pa sta edini alternativi brezbrižnemu narcisizmu, ki vodi v nič. Kritični pogled usmerja v dehumanizacijo, nezavedanje katastrofalnih posledic pohlepa in nerazumevanje razlogov za protest. Erotiko predstavlja kot navezanost, pogrešanje, zaskrbljenost za ljubljeno bitje, ki je daleč, kot strastno željo, strah pred izgubo in dvom o možnosti ljubezni sploh. Čustva izpoveduje v pismu, dvogovoru, dvojinskem izrekanju in prvoosebni izpovedi, sicer pa je govor brezoseben opis prizorišča in fotografije, poročilo, zgodba, trčenje več perspektiv.

Vizualno in taktilno bogate, dinamične podobe ponazarjajo naravne in antropološke zakone: voda je prvinska moč, večni ritem valovanja, osvajanja in umikanja, vzpenjanja in padanja, uresničenja ciljev in samopouživanja v dvodelni pesmi Interferenca, tekočina, svetloba in zvočno valovanje ponazarjajo odmiranje ljubezni v pesmi Drobtine. Retorika hiperbol, ponavljanj, naštevanj stopnjuje emocionalni naboj in ustvarja močan ritem. Ob taki jezikovni spretnosti je razumljiv pesničin dvom v poenostavitve in mačistična sporočila v popularni kulturi: filmski detektiv pozablja posameznike, ko se ukvarja z reševanja sveta (James Bond je in ni imel prav), ob končani ljubezni se izkaže puhlost besed iz popevk, svetovni rekordi in v naslovu PÓ $\Delta O \Sigma$ skriti izrek "hic Rhodus, hic salta« razlikujejo resnične dosežke od nastopaštva. Tudi z motivom fotografije v pesmih Ptička in 
Morda je Praga se pesnica odmika od dominantne vizualne kulture. Posnetek zaustavi tok dogodkov, daje iluzijo stabilnosti, lep videz krepi samoljubje, toda vse to zakriva bistvene zaznavne, čustvene in eksistencialne procese. Motiv potovanj po Evropi iz prve zbirke (Mladi ljudje na vlakih) poglablja prozna pesem Niso potovanja. Tu potovanj ne sproža svobodna mobilnost in radovednost, ampak srečanja, izmenjave, trenutki, ko si hvaležen življenju, ljubiš svet in lastno živost, čeprav ne moreš ničesar ohraniti ali nadaljevati in z doživetji lahko le "pojiš svojo samoto«. Spoznanj lastne krhkosti in osebnih preobrazb ni na fotografijah, ker je bistveno, "zakaj smo šli. Do česa smo prišli.«

Tri zbirke vsebujejo velik razpon usod, spoznanj, stališč, čustvenih odtenkov, četrta pa kroži okrog razdejanja ljubezenske dvojice, ki pretrese celotno telesno in psihično bitje. Koncentracija je učinek ritma, sintakse, pravopisa in dramaturgije. Besedila nimajo ločil in velikih začetnic, besede se ponavljajo, verzi se ne ujemajo s skladenjskimi enotami - besede celo delijo - poante so odprte, nedoločene, kar vse otežuje in upočasnjuje razumevanje. Zasopla govorica izraža razsuto duševnost, ki se bori za ostanke smisla, skuša vzdržati naval destruktivnih občutij, ne more logično misliti, asociativno preskakuje med simultanimi spominskimi drobci. V eksperimentalnem zasnutju besedil se pesnica sklicuje na dediščino neoavantgardne skupine OHO: "oho kaj pa je to uho" (šesti čut, 2 uho) in se prvič poigrava s homonimi in aliteracijo: "v prst posadim prst / posedim počakam« (šesti čut, 5 prst); »trda topa temna tvar otipljiva" (nenadoma). Dramatični potek se začenja z zanikanjem prihodnosti, "da ne bo več prišla« (da ne). Odziv na odpoved je cikel šesti čut, pošastna zamisel uničenja lastnih čutil, očesa, ušesa, nosu, jezika, prstov. Ukinitev čutenja in doživljanja druge se izteče v počasno tlenje delov telesa pod nasuto zemljo, ostanek zoglenitve pa bo "šesti čut«. Destilaciji in sublimaciji sledijo praznina, ${ }^{5}$ mrak, sence, hlad, tišina, apatija, toda zelo počasi, kot komaj zaznaven vzgib - tiktakanje, sev svetlobe, iskrenje, zgoščanje kosmov, nihaj lista v vetru, trzanje - se nakazuje popuščanje odrevenelosti, premagovanje notranjega konflikta, nato utrip življenja, krhek majav mostič, pripravljenost na vzpenjanje, čeprav v subjektu še divjajo maščevalne misli ali pa sta notranjost in zunanjost enako votli: "znotraj nič [...] zunaj nič, vse pol / no ničesar (znotraj). Minuli užitek in sedanja bolečina se vseskozi dogajata na telesni, čutni, predrazumski ravni. Samoopazovanje šele naknadno proizvaja spoznanja: da se ljubezni ne da izsiliti: "pustiti človeka ki jo ljubiš si jo / da sprhni po lastni volji / v senco skico v nič«, da ne traja večno: »jubezen / predpostavlja dvojino a tudi / njen razkroj« (to ni moj boj), da se dvoje ločenih črt, nians, življenj zgolj na videz stika, izenačuje, zliva $v$ eno zgolj navidezno obzorje. Čustveni poraz sproži misel o nujnem dopuščanju svobode: „Ne pozabi kako / nemogoča beseda je beseda / svoboda in kako šele / kako pojem (prostor). Zadnja pesem se kot kontrast vrača $\mathrm{k}$ uvodni; naslovni prislov že napoveduje vznemirjenost, pripravljenost, pričakovanje, sprejemanje, priznanje želje, postavljanje osi, okrog katere se bo znova vrtel svet.

Pesnica samoanalizo razširja na refleksijo o stanju človečnosti, jezika in poezije. Odgovor na vprašanje, kaj naj nesrečni storimo s sabo, ni »raztreščiti telesa«, temveč ljubiti odsotnost, praznino: »jubimo sneg kot na / tanko sneg nas (kaj naj). Dvom o jeziku meri na nepristnost, površnost,

5 Ob vseh nikalnih oblikah glagolov, samostalnikov in pridevnikov je najpogostejša beseda nič, ki pomeni izbris in praznino. Podpira ga oprema knjige: bele trde platnice, prazna naslovnica, naslov in kolofon na zadnji platnici, francoska vezava z razkritim hrbtom in roza šivi, ki delujejo kot razgaljena krhkost. 
onesnaženost, beg pred izpovedjo, toda brez jezika sploh ni mogoče misliti: »tenka misel tenko ponikne $v$ kašče besed v vrvohodce vmes / nos ti (kaj naj 2). Poezija je vidik pomiritve, znamenje živosti: "počasi poezija prihaja pomiritev z vsem / kar sem pripadam zlagoma rastem « (december), zato je prej eksistencialna kot estetska kategorija: »ne / poezija / življenje« (ne da ne).

Nina Dragičević (1984) je sociologinja (z doktoratom), svobodna umetnica, raziskovalka zvoka, pisateljica in pesnica. Kot didžejka, radijska spikerka in performerka je z glasbo v klubih/ lokalih in s predavanji o zgodovini skladateljic sooblikovala kulturo lezbičnega prostora. Iz posnetih realnih zvokov ustvarja instalacije in elektroakustične kompozicije (Parallelax, 2016; "Gospa, tega $v$ realnosti ni.«, 2019), piše eksperimentalno avtobiografsko prozo (Kdo ima druge skrbi, 2014), feministične muzikološke študije (Slavne neznane, 2016; Med njima je glasba, 2017) (prim. spletno stran nina.dragicevic.com). Njen interes je zvočnost kot neizbežna in preslišana pojavnost, $v$ kateri odmevajo dominacija, hegemonija, normativnost in nadzorovanje. Sodobna odtujenost je rezultat razredne, patriarhalne, heteroseksualne družbe, ki izključuje nacionalne, ekonomske, spolne in seksualne manjšine. V sferi zvočne umetnosti »odtujitev od specifične identitete [...] implicira razslojevanje subjekta (do točke desubjektivizacije) in parcialno reprezentacijo (do točke raztelešenja).«(Dragičević 2016: 250).

Ljubav reče greva (2019) je ritmično organizirana poema. Fragmente urbane resničnosti povezuje prvoosebni ženski subjekt, ki hodi, posluša, govori in misli, s čimer se dejavno upira uničenju posebne identitete in telesne eksistence. Predstava hoje ( $v$ ponovljenih glagolih grem, se obrnem, zastanem idr.) predpostavlja prostor, ki tu ni fizična resničnost, ampak družbeno-jezikovna struktura, oblastni sistem, ki proizvaja birokratsko govorico. Institucije s svojimi uradnicami imajo moč odločati o posamezničini usodi: potrdilih, prispevkih, objavah in gostovanjih, pogodbenem delu, celo o zdravljenju.

$\checkmark$ govorjenih in mišljenih drobcih vznika socialno ozadje poslušalke: ona je hči priseljencev, očeta so skoraj izbrisali iz registra državljanov, del njene identitete je hrvaški, zaradi grlenega izgovora glasu R (»je napaka«), mora dokazovati, da razlikuje med (trdim) slovenskim fonemom Č in (mehkim) južnoslovanskim Ć, ${ }^{6}$ ko dobi status umetnice, domači ne dojamejo, da s tem ni dobila službe, temveč le »dovoljenje biti kaj« (30), sliši celo namig, naj si iz stiske pomaga s telesom: "tvoje ti je tjelo dobar zanat« (27). V govoru drugih so prepoznavne družbene norme (kaj je koristno, učinkovito, donosno, pravilno, čisto, zdravo), odnos do drugačnih (homofobija, ksenofobija, mizoginija, toleranca nasilja) in občutja (sovraštvo, strah, prezir, ponižnost, gnev). Zvočna pojavnost seva razredni prepad: privilegirani zaposleni si privoščijo zabavo, negovanje telesa, zdravo hrano, počitek, turizem ipd., za vse to so prikrajšani prekarni pogodbeni delavci, brezposelni, umetniki, ki morajo nenehno dokazovati svoje kompetence, prositi za socialno pomoč, se izčrpavati v boju za preživetje in požirati očitke o brezdelnosti: "dajte že brezposelni kaj narediti iz sebe.« (24) Registriranje, analiza in interpretacija zvočnosti kulminira $v$ oznaki bobneči urbani blodnjak z nevarnimi detonacijami teles-min. $V$ javnih prostorih (knjižnica, tržnica, uradi, radijski studio, bolnišnica, kavarna, klub)

6 Odlomek, ki se dogaja na radiu, kjer subjektka "vadi govor« (str. 27-29), je leta 2018 zmagal na natečaju Pesniški turnir v Mariboru kot najboljša pesem po izboru žirije in najboljša pesem po izboru občinstva. 
obstaja mnogo oblik nasilja: polaščanje, kraja intelektualne lastnine, izkoriščanje, izločanje, udrihanje, prostaško zmerjanje, ponudba podcenjenega dela: „v isti sapi reče / tako čista je moja prijateljica je umetnica je najčistejši / človek je moja prijateljica [...] veš, kako natančno mi je / spucala stanovanje« (56).

Urbani blodnjak je brez središča in brez izhoda: ponavljajoča se vprašanja »kam le?«, »kaj le?«, »kdo le?«, »kaj naj? « so retorična, vsebujejo negativen odgovor: nikamor ni mogoče pobegniti, nič se ne bo spremenilo, nihče ne more odrešiti bolne družbe, ničesar ne morem doseči. Ljudje so izgubili smisel za solidarnost in empatijo, vizijo drugačnih odnosov, moč za politično akcijo. Fragmenti govora so replike neenakovrednih govorcev v uradni komunikaciji, $v$ kateri dialogi niso možni zaradi nerazumevanja položaja drugega, nezmožnosti in nepripravljenosti reševanja problemov, oviranja s postavljanjem nemogočih zahtev. Stranka javne uprave, medicinske ustanove, nevladne organizacije je prestrašeni (ustrahovani) objekt manipulacije in izkoriščanja, vse njene intervencije - prošnje za pomoč, predlogi in ponudbe - se končujejo z začudenjem, razočaranjem, odhodom, obupom in novim zagonom: mor'š zdržat.

Tenka, a ključna plast besedila je vzpostavljanje in utrjevanje ljubezenskega odnosa. Ljubav je pisateljica, aktivistka, mojstrica preživetja, modra od vednosti o uničenih ženskah v zgodovini, ${ }^{7}$ zaradi kritičnosti je žrtev onemogočanja in šikaniranja, brez dela in honorarjev: „ve, kaj bom rekla, upa, da bom, da bo končno povedala, da / nima za živet [...] ko reče colette ni imela za živet, so pomagali frendi, rečem / ethel ni imela za živet, so pomagali frendi, / reče vidiš rečem kaj reče, ko torej tolaži, ko šele mnogo / kasneje reče / kakšen zločin. « (18). Nobena ne odneha, vztrajata, se podpirata, borita, srečni, ko sta skupaj pri eni ali drugi doma, čeprav se zavedata, da izolacija ni rešitev, ker družbeno nasilje vdira vanju in njun skupni čas: »ljubav reče lepo je, ko sva sami, / a nisva sami, predvsem so tu vsi vpeti prepredeni šrapneli / šakali« (79).

Ob izvirni zvočni dimenziji je Ljubav reče greva tudi jezikovno inovativna pesniška knjiga: večglasna celota je komponirana iz birokratskih fraz, vulgarizmov, socioloških terminov in ekspresivnih oznak. Princip kompozicije je razvijanje ob ponavljanju glasov, besed, zvez, stavkov, onomatopoej (vrə, bm, ššššššš hə, hm, ou, ə). Ponovitve so način ritmičnega urejanja, segmentiranja in vezanja, kot ostinato v glasbi, v besedilu pa podpirajo pomen neizbežnosti, monotonije na eni strani in obvladovanja, osvobajanja, vztrajanja na drugi. Zvočno-ritmična razsežnost vabi v govorno izvedbo in avtorica to počne s presunljivo energijo. ${ }^{8}$

Kaja Teržan je odraščala v Škofji Loki in na Švedskem. Študij umetnostne zgodovine in sociologije na Filozofski fakulteti v Ljubljani je prekinila, da bi se posvetila sodobnemu plesu. Živi v Ljubljani in dela kot pomočnica vzgojiteljice v vrtcu. Zbirka Delta (2015) je bila nominirana za Veronikino nagrado, Krog (2018) nagrajena z Jenkovo, obe sta sprožili vabila na branja v Sloveniji

7 Spisek obsega Zofko Kveder, Colette, Virginijo Woolf, Elisabeth Bishop, Ano Ahmatovo, Ethel Smyth. O erudiciji priča tudi sklicevanje na Tina Ujevića, Johna Cagea, Samuela Becketta, Ivana Ščeglova, Helene Cixous, Rolanda Barthesa idr.

8 Po izidu je celotno knjigo brala v Narodni galeriji (23. 4. 2019) in na festivalu Mesto žensk v Stari elektrarni (7. 10. 2019), ob eksperimentalni glasbi Žige Jenko in vokalnem performansu Anje Novak. Zbrala pa je tudi dvajseterico literarnih znancev za maratonsko branju v Društvu slovenskih pisateljev (31. 5. 2019). 
(nastopa s kontrabasistom Joštom Drašlerjem ali pianistko Manco Udovič) in tujini ter prevode. Svojo neobičajno umetniško pot je opisala $v$ intervjujih, preusmeritev od plesnih performansov v poezijo pa v eseju Ples in poezija - prostor za subjekt. Med študijem in plesno prakso je spoznala, da se ni pripravljena podrediti utečenim vzorcem učenja in začela slediti lastnim prepričanjem, iskati smisel $v$ umetniških naključjih, take trenutke razširiti v novo zavedanje in s tem na novo določiti odnose in jezik.

Naslov zbirke Delta prihaja iz enako naslovljene pesmi, vprašanja, kako izbrati svojo življenjsko pot in kakšna je cena osebne svobode. Prelivanje med omejeno strugo reke in brezmejnim morjem simbolizira vodilno temo, tj. proces oblikovanja posamezničine identitete, uveljavljanje pravice do lastnih načel, dejanj, resnice ter predano, pristno in dosledno ravnanje, čeprav v nasprotju $s$ pričakovanji. Pri tem pesnica uporablja več perspektiv, npr. zamisel odzivov drugega na jaz, govor v imenu drugega, izpoved $v$ tretji osebi, presoja preteklosti s sedanjimi spoznanji.

V notranjem razčiščevanju so bistveni spomini na doživetja z bližnjimi sorodniki in zavezujoči čustveni odnosi. Socializacija je posiljevanje in utišanje otroka: "Vse gre brez posveta s tabo. / Dokler ne odpade lubje v kosih / in je podrast tista, ki te hrani." (Ekstrakt spomina) in taka je bila tudi njena v disfunkcionalni družini, ki je deklico odvračala od samostojnosti: "želim ti, da bi se pošteno raztreščila« (Razdrobljena skala) in se norčevala iz njenih strahov. Šele odrasla je spoznala, da lahko naklonjena in odprta intimna skupnost živi sproščeno in svoje člane sprejema v vseh preobrazbah, ne glede na veljavne norme: "In če odideš, se lahko vrneš s spremenjeno frizuro in drugačno obleko in vsi se bodo čudili, kako neverjetno simpatičen! je ta novi tujec " (Dan se je začel). Pretrgane vezi s straši, prijatelji, sostanovalci in partnerjem pomenijo izgubo otroštva, iluzij o srečni družini in ljubezni.

Subjekt se vzpostavlja z uporniškimi kretnjami, jasno predstavo o svoji prihodnosti, a tudi $z$ bolečo odpovedjo. Ključna zareza v odraslem življenju ženske je materinstvo: "Spremenljivo - / beseda, ki se izmika sama sebi. / Kot skrbi noseče ženske, ki s prihod-nostjo / izgubljajo vse, za kar si prizadevajo. "Spremenljivo -). Z nosečnostjo se podre tudi ljubezensko razmerje, saj moški ni pripravljen na očetovstvo in pobegne. Zanjo to ni rešitev: "Moja ljubezen na žalost ni človek; / ne morem preprosto odkorakati stran. “(Priznanje), lahko se le ukine kot nekdanja ljubica: „Ženska, ki je bila s tem moškim, / ne obstaja več« in odloči se ostati sama z otrokom.

Samota je tveganje nesprejetosti, vendar jo implicira že fizično telo: »Telo je moj dom."(Vse najboljše) Tu je začetek osebe, izvor njene svobode, mimo funkcij, položajev, preoblek in poimenovanj, podeljenih od zunaj, središče zaznavanja, zavedanja in ustvarjalnega izražanja s plesnimi gibi. Ples je užitek, tudi če ga zabave željna publika ne gleda, ne ve, kakšne priprave so v ozadju predstave, ali ga pojmuje kot bolezen. Za živo gibanje subjekt potrebuje prostor: "Rada bi imela svoj, samo moj prostor / tako kot v otroštvu« (Razdrobljena skala). Če naj bi omogočal sproščenost in samostojnost, bi moral biti odprt, amorfen, skoraj metafizičen, njen pa je majhen, v zgradbi ob pokopališču, ves čas ga je treba "graditi, popravljati, odstranjevati bakterije, razkuževati«. (Stonehenge, malo drugače) Samo v gozdni naravi pesnica doživlja "enostavna počutja; osvobojena vznesenosti« (Pričakovanja letnih časov), saj tam ni statike tujih predmetov niti oprezanja neznancev kot v lokalih, na ulici, železniški postaji, v avtobusu. Prostorski rez zasebno/javno se križa z razliko subjekt/objekt opazovanja. Opazovanje se ustavlja pri zunanjem videzu, ne sega do 
kompleksnih identitet posameznikov, a šele kot predmet tujih pogledov se jaz zave, kako poljubne in z normami pogojene so ocene drugih. Družba je v tej poeziji negativno ozadje, nabor nepristnega ravnanja, površnega vrednotenja in igranja vlog, čeprav si tudi jaz priznava ujetost v generacijo in v družbeni spol, tj. vzgojenost za ljubko nebogljenost in predvidljiv scenarij življenja.

Nekonformizem kažejo pesmi, ki opisujejo bizarne sanje. V nadrealističnih transformacijah jaza in stvarnosti so potlačeni strah, sram, tesnoba, krivda, nemoč in norost. Teh skritih projekcij poezija ne razreši, bodisi zaradi estetske klavzure (»Ni vse za v pesem«; Na primer) ali zaradi pojmovanja sebe: jaz se nima za izjemno, vendar vase zaverovanim avtoritetam, ki v naprej vedo in znajo vse, ne dovoli vdirati čez ris svoje zasebnosti.

V zbirki Krog se odpiranje prostorov svobode izteče v boj za preživetje matere z otrokom. Subjekt govori z družbenega roba: ostala je brez doma, nenehno se seli, živi v pomanjkanju, med »eksperimenti« v negotovih situacijah doživlja nemoč in odpor, bojuje se s strahovi in travmami. Vse to je daleč od stereotipov uspešne mame, prijateljice, ljubimke, hčerke, vzgojiteljice in umetnice. V svetu potrošništva in brezbrižnega individualizma je »nekvalificiranost za pridobitev večje količine materije (Dimenzije očesa) razumljena kot krivda, stigma, ki sili v podrejenost, ponižanje in molk, jaz pa vztraja pri osebnem dostojanstvu: „Zaužila bom svoje brezdomstvo, kakor da bi uživala sadje dreves / iz najplemenitejše zemlje.« (Plodovi). Njena samoobramba je praktično preskušanje vrednot, varnosti, občutljivosti in ljubezni. Najbolj pa se oddaljuje od tradicionalnih predstavitev materinstva, saj to zanjo ni srečna izpolnitev, ampak zapuščenost in odvisnost od socialne pomoči. Patriarhalni vzorci so ohranjeni v moškemu privlačni ideji o otrocih, ki ji ne sledi praksa dveh partnerjev, po njegovem je ženska sama kriva, če svet ne sprejema njene samostojnosti.

Iz stisk se rešuje z zapisovanjem bolečih obsesij, mislijo o stalnem spreminjanju, manjšanjem subjektivitete in uživanjem v naravi. Krute vizije in scenariji so izrecno proizvodi strahu. $\mathrm{V}$ temnih, zaprtih prostorih prežijo nočni plenilci, kače, grozljive črne maske ali smrt, sovražna bitja $v$ lastni notranjosti se polaščajo ustvarjalnih potencialov. A kakor zevajoča rana postane Lina upanja, tudi brezno prežarja svetloba, ki izvira iz ustvarjalnega subjekta. Nove možnosti nakazujejo hitri rečni tok, bežeča pokrajina med vožnjo, padajoči slap, žareči kraterji, zato niti preteklost niti sedanjost nista stalnici. Tek časa vsebuje idejo minljivosti, a za lirski subjekt, ki se s smrtjo sooča že od otroštva, nobena oblika naravnega padanja ni grozljiva: "Smrt je hkrati lepa in kruta, ker se ob njej zavem življenja. « (Obiskovanja) Izgubljenost, razbitost in želja po izginotju so prej povezane z dojemanjem sebe kot razpršene subjektivitete: "Najti delce sebe. / Najti delček sebe. Vsak / je pot domov. « (Kaj je s tišino) Pomanjšana in breztežna se zlahka istoveti z naravo: sekvoja, jesen, breze so zanjo merilo lepote, pokončnosti in kljubovalne rasti, v kanji, čaplji, detlu prepoznava voljo do življenja. V naravi se jaz zlije z okoljem: »utripam s kamenčki, deževniki in / vodo, ki teče pod stopali, da zorim počasi / iz svoje notranje kože« (Valjenje), izstopa iz svoje zavesti in se kot mikroskopsko majhna točka čuti v stiku z Vesoljem. Narava je prostor pomiritve, celjenja, uživanja, prebujene občutljivosti, srečanj s podobnimi sanjači. Kot celota je pozitivni kontrast uničevalni civilizaciji in družbi, v kateri ni več tišine, ljubezni, prijateljstva, nežnosti, domišljije, varovanja šibkih in sprejemanja neznancev.

Tudi erotika je ena od vrednot, ki jih doživljamo le še skozi njihova nasprotja. Eros je najprej trenutek popolnega stika, ko se raztaplja trdota in prostor čudežno odpira v neskončnost, toda čas 
ga usmeri v spoznavanje, besede, namere, pričakovanja, navajenost in usihanje, ljubljeno telo spremeni v balzamirano truplo, ženska se potem vrti v lastnem krogu, streznjena opusti iluzije, zadržuje izraze čustev, se umika nevarni bližini, želje po nežnosti preseli v sanje. Ob vseh samotnih in ranjenih ljudeh bi bilo dejavno izkazovanje ljubezni epifanija, mešanica groze in radosti, vendar bi bilo življenje bolj človeško, zapiše v pesmi Sanjarije agnostika.

Tako kot se erotične izjave ne strnejo $v$ zgodbo, je tudi ustvarjalnost prikazana s situacijami in prizori. Najbolj konkretni in fantastično preoblikovani so pesniški nastopi, saj si trpinčena, zaprta ženska ali delavka v vrtcu ne moreta/smeta privoščiti razkošja umetnosti. Z uporabo telesnih izrazov je pisanje pripeto na realno življenje: poezija je ogrodje, žarenje $v$ temi, proces ustvarjanja sebe, subjekt z njo napreduje, si nastavlja ogledalo, premaguje strahove. Boleče izkušnje sprožajo vztrajno iskanje pozitivnega in realno socialno prikrajšanost spreminjajo v simbolno moč. Govorica Kaje Teržan spaja podrobnosti individualnih izkušenj z abstraktnimi, univerzalnimi spoznanji, ko skuša ubesediti procese, ki se izmikajo vnaprejšnjim shemam. Prozne in kitične pesmi iz prostih verzov s sinkopiranim ritmom so polne prelomov, asociativnih preskokov in zamolkov, s čimer presegajo avtobiografski verizem.

\section{Literatura}

DRAGIČEVIĆ, Nina, 2016: Slavne neznane. Ljubljana: ŠKUC.

DRAGIČEVIĆ, Nina, 2016: Parallelax. Ljubljana: Kamizdat.

DRAGIČEVIĆ, Nina, 2019: "Gospa, tega v realnosti ni. “Opereta za gospe, violino in elektroniko. Ljubljana: Kamizdat.

DRAGIČEVIĆ, Nina, 2019: Ljubav reče greva. Ljubljana: Založba ŠKUC (Lambda 139).

GOLOB, Anja, 2010: V roki. Maribor: Litera.

GOLOB, Anja, 2013: Vesa v zgibi. Ljubljana: Mladinska knjiga.

GOLOB, Anja, 2016: Didaskalije k dihanju. Ljubljana: Samozaložba.

GOLOB, Anja, 2019: da ne da ne bo več prišla da ne bo da me žge da se odganjam [...] Maribor: Samozaložba.

HRVARTIN, Varja, 2020: Mojstrica multiplih realnosti. Neodvisni.art, https://www.neodvisni.art/refleksija/2020/03/ mojstrica-multiplih-realnosti (dostop 24.3.2021)

KOLŠEK, Peter, 2017: Četrt stoletja spremenljivih zvezd. Jože Volfand (ur.): Portreti sodobne slovenske literature 19912016. Celje: Fit media.

NOVAK POPOV, Irena (ur.), 2007: Antologija slovenskih pesnic 3. Ljubljana: Založba Tuma.

NOVAK POPOV, Irena, 2019: Uvodna skica za čitanje savremene slovenske poezije. Život LVIII/1-2. 279-283.

TERŽAN, Kaja, 2015: Delta. Ljubljana: Center za slovensko književnost (Aleph 171).

TERŽAN, Kaja, 2018: Krog. Center za slovensko književnost (Aleph 188).

TERŽAN, Kaja, 2015: Ples in poezija - prostor za subjekt. https://www.poiesis.si/kaja-terzan-ples-in-poezija-prostor-zasubjekt (dostop 21. 3. 2021) 